\title{
Michael Gross: 25 Years of Dedication and Leadership of JASMS (1990-2015)
}

Dear Mike,

What words or thoughts come to my mind when I think of you as a scientist, a person, a mentor, a singer, and as THE editor of the Journal of the American Society for Mass Spectrometry (JASMS)? You are hardworking, creative, intelligent, visionary, charismatic, and you have the tenacity to surmount almost anything, all balanced with an outstanding sense of humor and wit. It is hard to believe that you have led the Journal since its inception 25 years ago. I asked several of those who worked closely with you during your reign of JASMS to provide prose regarding their appreciation and perspective on you Mike, a true living legend. They are heart-felt and consistent with the feelings of all who have had the great fortune to interact with you.

Ron Hites: JASMS was founded in 1990. Once the Board of Directors had completed the publishing arrangements with Elsevier, the discussion turned to the selection of the founding editor of the new Journal. There were a range of options available to us - a glance at the authors of the papers in Volume 1, Number 1 will give you some idea of these folks - but we wanted an experienced editor, who would be respected by everyone but not be irritating. In other words, we wanted a nice guy with high standards. At that time, Mike was the editor of Mass Spectrometry Reviews, so we knew he had the editor's skills to do the job, and everyone on the Board knew Mike had the people skills to keep both the author and reviewer pools happy. Mike was the unanimous selection of the Board, and I was charged to call him and talk him into taking the position. I was successful.

In the early days, we would occasionally have dinners with Mike, selected ASMS Board members, and one or two honchos at Elsevier. At one such dinner, it was decided that everyone at the table would recite their favorite poem. One of the Brits from Elsevier started and did 10 minutes of Kipling, I did 1 minute of Ogden Nash, Mike did 5 minutes of Sandberg, and everyone else was forced to pass. ASMS was lucky to have Mike at the helm of the Journal for 25 years, and the entire mass spectrometry community will miss him in this role.

Kelsey Cook (Associate Editor, 1990-present): Being the only Associate Editor to have survived all 25 years (!) of Mike's term as Founding Editor-in-Chief, I am perhaps the most indebted and grateful to him. I certainly was among the most surprised, when, in June 1989, the phone in my Bergen, Norway, hotel room rang, and there was Mike, calling to ask if

Correspondence to: David C. Muddiman; e-mail: dcmuddim@ncsu.edu

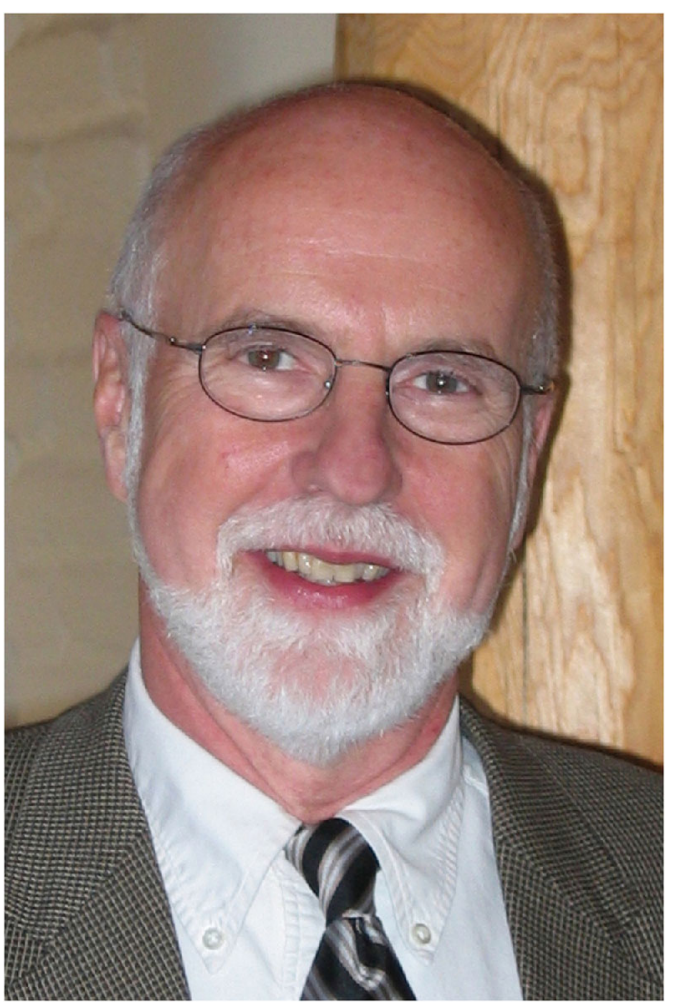

I'd be willing to serve. Flattered and excited, I said "yes" even before he said there would be a small stipend; "They actually pay people for this?" was my naive thought. For the ensuing 25 years, Mike has chipped away at my naiveté, serving as an insightful and incisive leader, teacher, and mentor, with a clear vision that has guided the Journal from infancy to leadership. The review management skills he taught have served me well not only in my editorial duties, but also on the job in Arlington. The evolution of the Journal from all paper through on-line submission to full electronic management has helped me recognize that our Journal is far more modern than is our Government. Seeing Mike soldier through transitions-from Lincoln to St. Louis, from Elsevier to Springer, from Lorraine Moon through Kathy Armstrong to Joyce Neff, and, most poignantly, from Judy to Paula, has been inspiring. His technical mastery, creativity, and productivity have been equally inspiring, albeit far more difficult to even dream of emulating. When Mike launched the Journal (with Gary Glish, Simon Gaskell, Sam Houk, and me), the idea was that Mike would be the sage leading the young team for a dynamic new undertaking. In many ways Mike has grown younger. It was an honor to write 

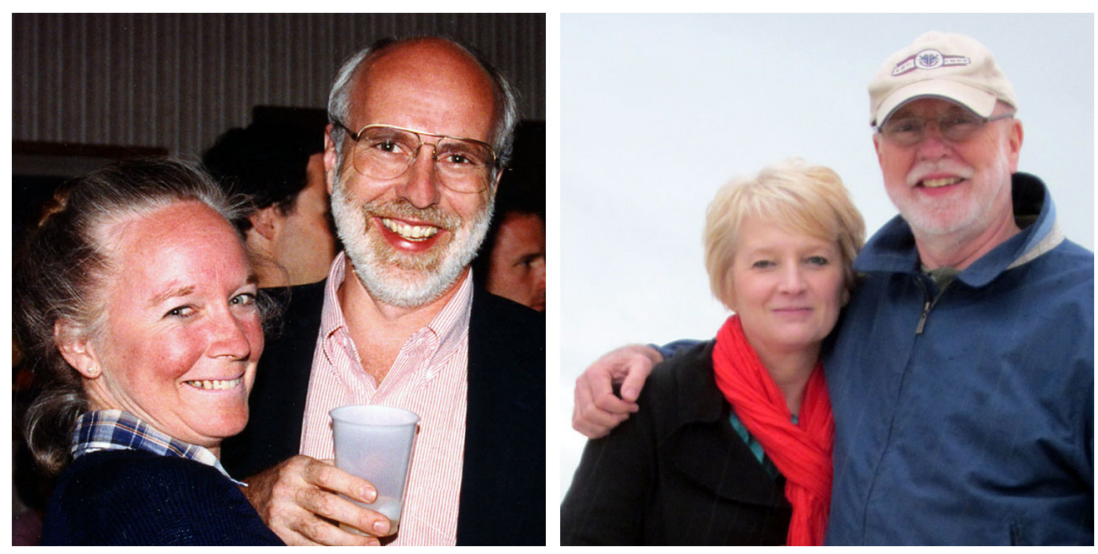

\section{SIDEBAR}

Mike describes his marriages as the "bookends" in his editorial tenure at JASMS as they played a major role in his life. The 1989 photo (left) is with his wife Judith who succumbed to breast cancer in 2003. The photo on the right is with his wife Paula; they married in 2007. We thank Mike but also his late wife Judith and current wife Paula for their strong support of the scholar, the leader, and the gentleman; in essence the man who took an idea of a society Journal and turned it into the international symbol of excellence in the field of mass spectrometry. Mike, you are deeply appreciated, you are loved, and you will be missed but never forgotten!

the editorial marking Mike's 65th birthday, and I am honored, if slightly saddened, to contribute to this tribute. Thank you, friend. May the next 25 be even better than the last-as productive, less poignant, and even more fun.

Simon Gaskell (Associate Editor, 1990-1999): The debt that ASMS - and the worldwide mass spectrometry community - owe to Mike is enormous. It's easy to forget after 25 years that the success of JASMS was by no means a foregone conclusion - were there not enough MS and analytical chemistry journals already? I believe it was Ron Hites as ASMS President who was particularly convinced of the value of the new Journal but it was the brilliant decision (presumably reached formally by the ASMS Board of the time) to invite Mike to be Editor-in-Chief that did much to ensure its success. I was delighted to be invited to join him (along with Kelsey Cook, Gary Glish and Sam Houk) as one of the Associate Editors-I was on the faculty of Baylor College of Medicine at the time. In 1993, when I moved to Manchester, UK, Mike evidently decided that it was acceptable to have a foreigner as one of the editors (!) - perhaps a modest indicator of the position that JASMS had reached under Mike's leadership, as a Journal whose reach had become truly international. The experience of being one of the editors was, however, more than just satisfying from a professional point of view-it was also great fun. Mike has this style-combining humor, mischievousness, and a useful dose of irreverence - that ensures that serious work can be done, often over drinks and dinner, without banishing laughter and enjoyment. I was privileged to be part of that for several years and the memento of a miniature cover (the old style!) of JASMS encased in perspex remains in pride of place on my office bookshelves. Mike will be a very hard act to follow-I wish that brave individual every success!

Gary Glish (Associate Editor, 1990-2007): I first met Mike when I was a graduate student at Purdue. We took a road trip to the University of Nebraska for the grand opening of the
NSF Midwest Center for Mass Spectrometry. I won't say when this was, but the centerpiece instrument was an EBE. Even though Mike was extremely busy with all the activities associated with the opening, he made time to interact with us grad students. I immediately appreciated Mike's openness and friendliness, traits that I think anyone who has interacted with Mike has experienced. I consider him to be the epitome of a scholar and a gentleman. Mike became a second mentor to me and I have truly valued his mentorship and friendship over the years. I was honored to be asked by Mike to serve as an Associate Editor of JASMS at its inception. Mike was the perfect choice as the founding editor. He has done an outstanding job guiding the Journal and was always open to suggestions (and badgering) from the Associate Editors. I always looked forward to the editors' dinner at ASMS, it was one of the highlights of the week because of the interactions Mike fostered among the editorial team (and Mike's culinary selections). He will be missed as editor, but not forgotten.

Sam Houk (Associate Editor, 1990-1994): Mike Gross was a great person to work with at JASMS. He made a deliberate effort to be sure ALL areas of mass spectrometry were represented in the Journal. In cases where problems arose with papers or authors, he was willing to discuss the situation at length with the appropriate Associate Editor. The JASMS board meetings were run efficiently and provided very useful feedback to the Associate Editors. Basically, Mike is/was a consummate professional in every way. He always treated everyone like family (i.e., he treated me better than I deserved)! I learned a lot about how to deal with difficult situations and people from watching his example, and from looking into the mirror. Best wishes Mike!

Veronica Bierbaum (Associate Editor, 1998-present): Michael, it's hard to believe that 40 years have passed since we first met on the shores of Biarritz! (Of course, we were both young children at that time...) And while the endless 
possibilities of youth are exciting, it is much more satisfying to reflect on the accomplishments of an incredible career. Throughout the decades, I have been an admirer of your superb chemistry and your invaluable service to the community of scientists; I have deeply appreciated your mentorship, friendship, and support both in science and in life. Thank you for your vision, inspiration, and leadership in making JASMS a premier Journal of ASMS - your contributions have forever enriched our Journal and our beloved field of mass spectrometry!

Carol Robinson (Associate Editor, 2000-2013): Mike's time as Editor-in-Chief of the Journal was quite remarkable. His unstinting energy and tireless enthusiasm for mass spectrometry and the Journal were infectious for all of us as Associate Editors. For me he symbolized constant change to keep the Journal a vibrant and exciting publication. This was in no small part due to the fact that Mike always embraced new ideas. On one occasion I remember suggesting the introduction of a color figure to highlight interesting articles. Rather than protecting the existing cover and its history, Mike enthusiastically agreed to the change. Similarly when discussing the concept of the 'Critical Insight' articles it was clear that he was receptive to new directions and that he wasn't going to give me the opportunity to say 'no' to becoming the editor of this new venture. For all of these qualities, as well as his numerous personal attributes, his position as the Editor-in-Chief of JASMS will be very difficult to fill. Enormous thanks to Mike for his dedication and commitment over the last 25 years.

Jenny Brodbelt (Associate Editor, 2006-present): It is with sadness and admiration that I watch Mike Gross pass the baton to a new Editor-in-Chief of JASMS. I have been fortunate to be a part of the JASMS team of Associate Editors. Mike built a well-fortified foundation for the society's Journal, and the Journal has flourished and expanded in scope over 25 years. One could not ask for more dedication and integrity in a leader, and nicely balanced with humor and patience. Mike always carried the heaviest load and did so with unflagging enthusiasm. I applaud his years of leadership and congratulate him on a job well done.

Joe Loo (Associate Editor, 2007-present): It's hard to believe that JASMS has already reached its 25 th birthday. Mike ("From the Land of Sky Blue Waters") Gross has been the steadying force who has guided and shaped the Journal from its birth, and he continues to lead our Journal with the same energy as when JASMS started in 1990. It seems like only yesterday when a red-covered Journal would show up in our mailboxes every two months. (Remember that JASMS was published bimonthly until 1993.) To submit manuscripts, we needed to mail four copies of our double-spaced typed paper to Mike's office in Lincoln, NE. Reviewers' comments would be returned by mail, and sometimes the package would include mark-ups of our paper handwritten by Mike himself. Times change, of course. Mike has moved from Lincoln to St. Louis, and he may have "aged for many moons, gently mellowed," but JASMS continues to have the same breadth and strength as it did in January 1990 because of Mike. I started to work for
JASMS in 2007 when Mike invited me to work for his team. Based on my first-hand experiences, Mike has done an exceptional job of steering the ship with a gentle, deft touch, sometimes through murky waters, but we always emerged with a clear path ahead. I consider Mike as one of my best mentors, and I am thankful for the guidance that he has provided to me and to the Journal. Somehow, I thought Mike would be Editorin-Chief forever, and that he would "go down with the ship." Not that JASMS will sink into the abyss anytime soon, but Mike is synonymous with "JASMS." (Coincidentally, Mike resembles the captain of the Titanic, Edward John Smith. Go ahead and "google" the name to see for yourself.) Although he reminded us that the "Journal belongs to you, the members of ASMS," (Editorial in JASMS, January 1993 issue) JASMS will always be Mike's Journal.

Richard O'Hair (Associate Editor, 2009-present): As a graduate student working with Professor John Bowie in the mid to late 1980s, I knew Professor Michael Gross through his ground-breaking work on charge remote fragmentation, which appeared while John's group was trying to uncover the role of charge in directing fragmentation. Mike's lab was clearly a "Mecca" for gas-phase ion chemistry as John sent several of his students on research visits (I got to visit the late Chuck DePuy instead). I think I met Mike for the first time as a postdoc at the Rocky Mountain Conference on Analytical Chemistry in Denver in 1992, where we spoke in the same session. Afterwards he came up to me for a chat and I was struck by his warm, friendly nature. Mike is a true gentleman, always having time for "one and all." At this end of an era, I wanted to thank you Mike for your friendship and leadership in being a founding father of JASMS!

Gavin Reid (Associate Editor, 2013-present): I'm sure that most people initially learn about the eminent scientists within our field via reading their contributions to the literature. As a graduate student, this is first how I got to know Mike, particularly with regard to his ground breaking work in describing charge remote fragmentation reactions of biomolecular ions in the gas-phase. However, getting to know the man in person over the past 10 years or so has been a much more interesting and enriching experience. It has been a sincere pleasure to be guided and mentored by Mike in my first Associate Editor role, and I am enormously grateful that he had the confidence in my abilities (that I'm not sure I had myself) to take on the position. The success of the Journal over the past 25 years has been as much due to Mike's gregarious personality and welcoming nature as it has to his incisive depth and breadth of knowledge, both historical and current, which has enabled him to expertly guide and shape the growth and focus of the Journal since its inception. It will take a very special person to fill the shoes left under the JASMS Editor's desk.

David Russell (Associate Editor, 2013-present): If you have read Malcolm Gladwell's book "The Outliers," you are at least aware of his thesis that in many cases success is determined by chance. That is, the willingness to take advantage of opportunities, often initially unrecognized, and people we encounter as we go through life, people who provide chance opportunities 
that impact our future and success or failure. It was by chance that I met Mike Gross in 1974. I was an entering graduate student, a Vietnam vet, trying to restart my life after several years of "adventures." Little did I realize the opportunities that were being placed at my feet. These opportunities included learning the exciting, relatively new field of gasphase ion chemistry, a suite of instruments and instrumental approaches that would later usher in the "age of proteomics," and opportunities to meet and talk with leaders of the day, Graham Cooks, Al Burlingame, Jack Beauchamp, Nico Nibbering, John Brauman, Dudley Williams, Keith Jennings, Frank Field, Fred McLafferty, and many others who visited Lincoln, Nebraska...the virtual capital of the "fly-over-states"! Mike was and is an outstanding mentor, not only to his students, but to anyone who is willing to pause for a few moments, in the isle at poster sessions, in a superb restaurant (his taste for such is second only to love of laughter), and yes, even in a noisy, smoke-filled hospitality suite (back when they really were about hospitality!). In my opinion, his role as "Editor" of JASMS for 25 years is simply an extension of his mentorship. Although he is stepping down as "Editor," I am certain that his "mentorship" to ASMS and related chemistry areas will continue. Thanks Mike, you are my HERO!!

Joyce Neff (Managing Editor, 1997-present): Thank you, Mike, for the pleasure of working with you for 17 years. We've seen a lot of changes in the Journal, but your guidance and support remained constant and meant a lot to me. The journey has been a wonderful experience that I will always treasure. Along with your enthusiasm and energy for JASMS, you have always been very proud and protective of it. It is like one of your children. I wish you great health, happiness, and continued success in all that you do. We'll miss you!

On behalf of ASMS, I sincerely thank you Mike for your dedication, commitment, and leadership to our society Journal.

With warmest regards and admiration,

\section{David C. Muddiman}

Member-at-Large for Publications, ASMS

Department of Chemistry

North Carolina State University

Raleigh, NC, USA

E-mail: dcmuddim@ncsu.edu 